\title{
Effect of the Levonorgestrel-Releasing Intrauterine System on the Uterine Artery, Uterine Volume, and Endometrium in Endometrial Hyperplasia without Atypia
}

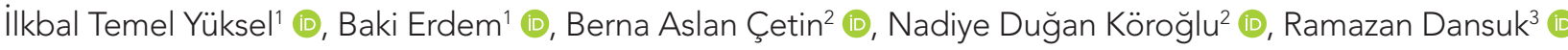 \\ 1'Department of Gynecologic Oncology, University of Health Sciences Kanuni Sultan Süleyman Training and Research Hospital, i̇stanbul, Turkey \\ 2Department of Obstetrics and Gynaecology, University of Health Sciences Kanuni Sultan Süleyman Training and Research Hospital, i̇stanbul, Turkey \\ ${ }^{3}$ Department of Obstetrics and Gynaecology, Biruni University School of Medicine, İstanbul, Turkey
}

Cite this article as: Temel Yüksel I, Erdem B, Aslan Çetin B, Duğan Köroğlu N, Dansuk R. Effect of the Levonorgestrel-Releasing Intrauterine System on the Uterine Artery, Uterine Volume, and Endometrium in Endometrial Hyperplasia without Atypia. JAREM 2019; 9(Supplement 1): S15-8.

\begin{abstract}
Objective: The aim of this study is to evaluate the effects of the levonorgestrel-releasing intrauterine system (LR-IUS) on endometrial thickness, hemogram parameters, and uterine artery Doppler results among women who have endometrial hyperplasia without atypia.

Methods: Fifty-four women who admitted to our hospital due to menorrhagia and with a diagnosis of endometrial hyperplasia without atypia treated with the LR-IUS were included in our study. The uterine artery measurements, uterine volume, alterations on hemoglobin concentrations, and follow-up endometrial biopsies after 6 months were analyzed.

Results: Fifty women completed the 6-month period. Among all these women, regression was recorded in endometrial hyperplasia. The uterine artery resistance index, pulsatility index, and uterine volume did not show any significant difference. Reduction in the endometrial thickness and increasing levels of hemoglobin and hematocrit concentrations were also determined.

Conclusion: LR-IUS may be used as an effective procedure and a confident alternative medical approach to oral gestagen therapy and surgery among women with menorrhagia who have simple endometrial hyperplasia without atypia.

Keywords: LR-IUS, uterine artery, resistance index, pulsatility index, power Doppler, endometrial hyperplasia
\end{abstract}

\section{INTRODUCTION}

Endometrial hyperplasia (EH) occurs as a result of a long-term exposure of the endometrium to estrogen in case of progesterone deficiency. Histologically, EH has been identified as a spectrum between the benign and the cancer precursor lesion $(1,2)$. The treatment strategies in $\mathrm{EH}$ can be divided into medical and surgical. Progesterone, combined oral contraceptives, danazol, and $\mathrm{GnRH}$ analogues are used in medical treatment. In surgical treatment, D\&C, hysterectomy, hysteroscopic endometrial ablation, or endometrial resection are performed $(3,4)$.

In the levonorgestrel-releasing intrauterine system (LNG-IUS), a daily low-dose of levonorgestrel (LNG) secreted into the uterine cavity causes a consistently high LNG concentration by affecting the endometrium only (5). The LNG-IUS locally affecting the endometrium directly causes its atrophy. As a result, a significant decrease in the extent of menstrual bleeding is observed (6). There are many studies reporting that LNG-IUS is effective and has less systemic side effects in the treatment of patients with $\mathrm{EH}(7-11)$.

The aim of this study was to evaluate the efficacy of LNG-IUS in the treatment of EH without atypia and its effects on endometrial thickness, uterine volume, and uterine artery Doppler parameters.

\section{METHODS}

The study was conducted in accordance with the principles of the Helsinki Declaration after obtaining informed consent from the patients. It included 54 patients in the premenopausal period who presented with abnormal uterine bleeding and reported EH without atypia as a result of endometrial biopsy.

After the gynecological examination of the patients who presented with abnormal uterine bleeding, the menstrual bleeding pattern was determined using illustrated menstruation cards. Endometrial sampling was performed under local anesthesia in pa-

ORCID IDs of the authors: i.T.Y. 0000-0002-7337-9977; B.E. 0000-0002-6407-8718; B.A.Ç. 0000-0001-6856-1822, N.D.K. 0000-0001-8337-3432, R.D. 00000002-5198-0884. 
tients diagnosed with abnormal uterine bleeding. Patients with $\mathrm{EH}$ without atypia were included in the study, whereas patients with submucous fibroids, endometrial polyps, or uterine anomalies were excluded.

Baseline hemogram parameters were recorded before the study. In transvaginal ultrasonography, endometrial thickness was measured in the longitidinal plane, and the uterine volume was calculated using the 3 planes for the ellipsoid masses $\left(4 / 3 X_{\pi} X D 1 X D 2 X D 3\right)$. The uterine artery Doppler velocimetry was measured longitudinally from the main ascending uterine artery at the level of the internal cervical bone. The Pulse In$\operatorname{dex}(\mathrm{PI}=$ [systole / diastole] / mean) and Resistance Index (RI = [systole-diastole] / systole) values of both uterine arteries were recorded.

LNG-IUS was inserted into the uterine cavity by the same gynecologist and obstetrician in the first 7 days of menstruation. Transvaginal ultrasonography was performed before and after the procedure to determine the correct placement of the LNGIUS. The patients were not given iron replacement, and blood products were not transfused until called for control. After 6 months, the patients were called for a control examination. In the midluteal phase, the endometrial sampling was performed again, and the uterine artery Doppler parameters and uterine volume were measured.

\section{Statistical Analysis}

The Statistical Package for Social Sciences for Windows 15.0 (SPSS Inc., Chicago, IL, USA) was used to evaluate the data obtained in the study. In addition to descriptive statistical methods

\section{Table 1. Morphological Characteristics of the Endometrium} After the LNG-IUS Treatment

\begin{tabular}{|l|c|}
\hline Decidualization & $40(80 \%)$ \\
\hline Secretion & $3(6 \%)$ \\
\hline Proliration & $3(6 \%)$ \\
\hline Atrophic glands & $2(4 \%)$ \\
\hline Stromal inflammation & $2(4 \%)$ \\
\hline
\end{tabular}

(average, standard deviation), a paired sample t-test was used for normal distribution parameters, and the Wilcoxon sign test was used for abnormal distribution parameters in the comparison of quantitative data. The results were evaluated at $95 \%$ confidence interval and at $p<0.05$ level of significance.

\section{RESULTS}

Although 54 patients were initially included in the study, 4 patients underwent hysterectomy due to severe vaginal bleeding over a 6-month period, and thus the study was completed with 50 patients. The average age of the patients was $45.31 \pm 4.94$ years, and the average body weight was $75.69 \pm 14.09 \mathrm{~kg}$. The patients were referred to the hospital due to metrorrhagia and menorrhagia.

Morphological features of endometrial biopsies in the 6th month were decidualization in $40 / 50(80 \%)$, secretion in $3 / 50$ (6\%), proliferation in $3 / 50(6 \%)$, atrophic glands in $2 / 50(4 \%)$, and stromal inflammation in 2/50 (4\%) (Table 1).

There was a significant increase in hemoglobin and hematocrit values after treatment $(p=0.002, p=0.006$, respectively). Endometrial thickness measurements decreased significantly after treatment ( $p=0.001$ ) (Table 2).

Uterin volüm değerleri, sağ ve sol uterin arter RI ölçümleri ve sağ ve sol uterin arter PI ölçümlerinde ise tedavi öncesinde ve sonrasında anlamlı fark saptanmadı $(p>0,05)$ (Tablo 2).

Uterine volume and RI and PI measurements of the right and left uterine artery did not show a significant differennce before and after the treatment ( $p>0.05$ ) (Table 2).

\section{DISCUSSION}

$\mathrm{EH}$ is a group of abnormal proliferation with heterogeneous features that form a broad spectrum. It is known that some of them are precursor lesions of endometrial carcinoma. The development of carcinoma in some of the untreated patients with hyperplasia and the detection of hyperplasia in many areas in some hysterectomy materials diagnosed with endometrial adenocarcinoma increase the importance of hyperplasia treatment (2). In our study, we found that the LNG-IUS application is an effective method in the treatment of EH without atypia and that it

Table 2. Comparison of Hemoglobin and Hematocrit Values, Ultrasonography Parameters

\begin{tabular}{|l|c|c|c|} 
& Before Treatment & After Treatment & p \\
\hline Hemoglobin (g/dL) & $11.47 \pm 1.97$ & $12.25 \pm 1.88$ & $0.002^{*}$ \\
\hline Hematocrit (\%) & $35.29 \pm 5.60$ & $37.36 \pm 5.00$ & $0.006^{*}$ \\
\hline Endometrial thickness $(\mathrm{mm})$ & $9.31 \pm 4.07$ & $5.78 \pm 1.67$ & $0.001^{*}$ \\
\hline Uterine volume $(\mathrm{mL})$ & $932.12 \pm 252.25$ & $933.11 \pm 253.27$ & 0.609 \\
\hline Right uterine artery PI & $1.72 \pm 0.72$ & $1.70 \pm 0.70$ & 0.915 \\
\hline Right uterine artery RI & $0.78 \pm 0.09$ & $0.79 \pm 0.15$ & 0.514 \\
\hline Left uterine artery PI & $1.68 \pm 0.59$ & $1.64 \pm 0.66$ & 0.733 \\
\hline Left uterine artery RI & $0.80 \pm 0.09$ & $0.78 \pm 0.17$ & 0.397 \\
\hline Pl: pulsality index; Rl: resistance index; ${ }^{*}{ }^{*}<0.05$ & & & \\
\hline
\end{tabular}


increases the hemoglobin and hematocrit parameters and decreases endometrial thickness.

Buttini et al. (12) performed the LNG-IUS in 202 patients with EH without atypia and reported a regression rate of $98 \%$. Varma et al. (13) reported the average regression time in simple $\mathrm{EH}$ and complex hyperplasia as 6.2 and 9.4, respectively, and detected that 15 of 16 patients with simple hyperplasia (94\%) underwent regression at $12^{\text {th }}$ months. Maruo et al. (14) found that the LNGIUS is effective in the regression of $\mathrm{EH}$ without atypia and that the $\mathrm{EH}$ regression is not only around the system but all endometrial thickness. In our study, the regression was found in all 50 patients who completed the treatment.

The LNG release in the uterus leads to rapid and dramatic changes. These include the morphological decidualization of the stroma, leukocyte infiltration, atrophy, and vascularization changes in the glandular surface epithelium. Secretory functions of the epithelial glands are lost, and the proliferation effect in the endometrium is inhibited. This causes thinning in the functional layer of the endometrium (15). In our study, the most common change in endometrial biopsies after treatment was decidualization by the pathologist (80\%).

It was reported in studies that the endometrial thickness decreases significantly in the 6th month of the $\mathrm{EH}$ treatment with the LNG-IUS (16-18). The LNG-IUS applied locally causes atrophy directly in the endometrium and reduces menstrual bleeding (6). In our study, it was found that the endometrial thickness decreased significantly in the 6th month of treatment.

Sheng et al. (19) found that the uterine volume at the 12th month was significantly reduced compared to the uterine volume at 6 months. In their study, Wildemeersch et al. (20) also found that the LNG-IUS provided a decrease in the uterine volume in patients with uterine myoma. In the study by Güneş et al. (21), a significant difference was not observed in the uterine volume changes. In our study, no change was detected in the uterine volume at 6 months.

In their study, Güneş et al. (21) compared the blood parameters before the LNG-IUS administration and 1 year after in 21 patients, and they reported a significant increase in the hemoglobin values. Many studies report that LNG-IUS is effective in the treatment of abnormal uterine bleeding. Increased hemoglobin levels have been reported in the long-term follow-up of women undergoing LNG-IUS (16-22). In our study, we found that hemoglobin levels increased by $0.78 \mathrm{~g} / \mathrm{dl}$, and hematocrit values increased by 2.07 units after 6 months. Hemoglobin and hematocrit levels were significantly increased in patients with LNG-IUS at the end of 6 months ( $p=0.006$ and $p=0.002$, respectively).

There was no significant change in the subendometrial vascularization in the Doppler ultrasonography examinations performed on the LNG-IUS patients. In the uterine artery Doppler ultrasonography of these patients, the PI and RI values were found to be increased, and especially the PI values were found to be significant (23). Pakarinen et al. (17) found no change in the uterine artery PI values in patients undergoing LNG-IUS. Jarvela et al. (24) evaluated the uterine artery PI values in the midluteal phase and showed an increase. Haberal et al. (25) found an increase in the RI values 1 year after the application of LNG-IUS, and they did not find any change in the PI values. The authors suggested that the increase in the Rl values may be due to progestational effect. In our study, we did not find any significant changes in the PI and RI values in bilateral uterine arteries. We found that the LNG-IUS application had no effect on uterine artery Doppler ultrasonography parameters.

\section{CONCLUSION}

The LNG-IUS is a safe and effective treatment of abnormal uterine bleeding and $\mathrm{EH}$ without atypia.

Ethics Committee Approval: Authors declared that the research was conducted according to the principles of the World Medical Association Declaration of Helsinki "Ethical Principles for Medical Research Involving Human Subjects", (amended in October 2013).

Informed Consent: Informed consent was obtained from the patients who participated in this study.

Peer-review: Externally peer-reviewed.

Author Contributions: Concept - I.T.Y.; Design - B.E.; Supervision B.A.Ç.; Resources - N.D.K.; Data Collection and/or Processing - B.A.Ç.; Analysis and/or Interpretation - N.D.K.; Literature Search - B.E.; Writing Manuscript - I.T.Y.; Critical Review - R.D.

Conflict of Interest: The authors have no conflict of interest to declare.

Financial Disclosure: The authors declared that this study has received no financial support.

\section{REFERENCES}

1. Atasü T, Kaleli S, Gezer A. Endometrial Hiperplaziler: Prekanseröz Lezyonlar olarak irdelenmesi. Jinekoloji ve Obstetrik Dergisi 1996; 10:195-201.

2. Uslu T. Endometrial Hiperplazi.-Güner H (editör). Jinekolojik Onkoloji Kitabı, 1. Baskı, Ankara, Çağdaş Kitapevi, 2002: 124-8.

3. Clark TJ, Neelakantan D, Gupta JK. The management of endometrial hyperplasia: an evaluation of current practice. Eur J Obstet Gynecol Reprod Biol 2006; 125: 259-64. [CrossRef]

4. Marsden DE, Hacker NF. Optimal management of endometrial hyperplasia. Best Pract Res Clin Obstet Gynaecol 2001; 15: 393-405. [CrossRef]

5. Lahteenmaki P, Rauramo I, Backman T. The levonorgestrel intrauterine system in contraception. Steroids 2000; 65: 693-7. [CrossRef]

6. Jensen JT. Contraceptive and therapeutic effects of the levonorgestrel intrauterine system: an overview. Obstet Gynecol Surv 2005; 60: 604-12. [CrossRef]

7. Wildemeersch D, Janssens D, Pylyser K, De Wever N, Verbeeck G, Dhont $\mathrm{M}$, et al. Management of patients with non-atypical and atypical endometrial hyperplasia with a levonorgestrel-releasing intrauterine system: long-term follow-up. Maturitas 2007; 57: 210-3. [CrossRef]

8. Orbo A, Arnes M, Hancke C, Vereide AB, Pettersen I, Larsen K. Treatment results of endometrial hyperplasia after prospective $D$-score classification: a follow-up study comparing effect of LNG-IUD and oral progestins versus observation only. Gynecol Oncol 2008; 111: 68-73. [CrossRef]

9. Varma R, Soneja H, Bhatia K, Ganesan R, Rollason T, Clark TJ, et al. The effectiveness of a levonorgestrel-releasing intrauterine system (LNGIUS) in the treatment of endometrial hyperplasia: a long-term follow-up study. Eur J Obstet Gynecol Reprod Biol 2008; 139: 169-75. [CrossRef]

10. Vereide AB, Kaino T, Sager G, Arnes M, Orbo A. Effect of levonorgestrel IUD and oral medroxyprogesterone acetate on glandular and stromal progesterone receptors (PRA and PRB), and estrogen receptors (ER-alpha and ER-beta) in human endometrial hyperplasia. Gynecol Oncol 2006; 101: 214-23. [CrossRef] 
11. Vereide AB, Arnes M, Straume B, Maltau JM, Orbo A. Nuclear morphometric changes and therapy monitoring in patients with endometrial hyperplasia: a study comparing effects of intrauterine levonorgestrel and systemic medroxyprogesterone. Gynecol Oncol 2003; 91: 526-33. [CrossRef]

12. Buttini MJ, Jordan SJ, Webb PM. The effect of the levonorgestrel releasing intrauterine system on endometrial hyperplasia: an Australian study and systematic review. Aust N Z J Obstet Gynaecol 2009; 49: 316-22. [CrossRef]

13. Varma R, Soneja H, Bhatia K, Ganesan R, Rollason T, Clark TJ, et al. The effectiveness of a levonorgestrel-releasing intrauterine system (LNGIUS) in the treatment of endometrial hyperplasia-A long-term follow-up study. Eur J Obstet Gynecol Reprod Biol 2008; 139: 169-75. [CrossRef]

14. Maruo T, Laoag-Fernandez JB, Pakarinen P, Murakoshi H, Spitz IM, Johannson E. Effects of levonorgestrel-releasing intrauterine system on proliferation and apoptosis in the endometrium. Hum Reprod 2001; 16: 2103-8. [CrossRef]

15. Ortiz ME, Croxatto HB. Copper-T intrauterine device and levonorgestrel intrauterine system: biological bases of their mechanism of action. Contraception 2007; 75: 16-30. [CrossRef]

16. Zalel Y, Shulman A, Lidor A, Achiron R, Mashiach S, Gamzu R. The local progestational effect of the levonorgestrel-releasing intrauterine system: a sonographic and Doppler flow study. Hum Reprod 2002; 17: 2878-80. [CrossRef]

17. Pakarinen $P$, Luukkainen $T$, Laine $H$, Lähteenmäki P. The effect of local intrauterine levonorgestrel administration on endometrial thickness and uterine blood circulation. Hum Reprod 1995; 10: 2390-4. [CrossRef]

18. Jimenez MF, Arbo E, Vetori D, de Freitas FM, Cunha-Filho JS. The effect of he levonorgestrel-releasing intrauterine system and the cop- per intrauterine device on subendometrial microvascularization and uterine artery blood flow. Fertil Steril 2008; 90: 1574-8. [CrossRef]

19. Sheng J, Zhang WY, Zhang JP, Lu D. The LNG-IUS study on adenomyosis: a 3-year follow-up study on the efficacy and side effects of the use of levonorgestrel intrauterine system for the treatment of dysmenorrhea associated with adenomyosis. Contraception. 2009; 79: 189-93. [CrossRef]

20. Wildemeersch $D$, Schacht $E$. The effect on menstrual blood loss in women with uterine fibroids of a novel "frameless" intrauterine levonorgestrel-releasing drug delivery system: a pilot study. Eur J Obstet Gynecol Reprod Biol 2002; 102: 74-9. [CrossRef]

21. Gunes M, Ozdegirmenci O, Kayikcioglu F, Haberal A, Kaplan M. The effect of levonorgestrel intrauterine system on uterine myomas: A 1-year follow-up study. J Minim Invasive Gynecol 2008; 15 : 735-8. [CrossRef]

22. Xiao B, Wu SC, Chong J, Zeng T, Han LH, Luukkainen T. Therapeutic effects of the levonorgestrel-releasing intrauterine system in the treatment of idiopathic menorrhagia. Fertil Steril 2003; 79: 963-9 [CrossRef]

23. Stekkinger $\mathrm{E}$, van der Linden PJ. A levonorgestrel-containing IUD for the treatment of endometriosis. Ned Tijdschr Geneeskd 2007; 151: 2372-6.

24. Järvelä I, Tekay A, Jouppila P. The effect of a levonorgestrel-releasing intrauterine system on uterine artery blood flow, hormone concentrations and ovarian cyst formation in fertile women. Hum Reprod 1998; 13: 3379-83. [CrossRef]

25. Haberal A, Kayikcioglu F, Gunes M, Kaplan M, Ozdegirmenci O. The effect of the levonorgestrel intrauterine system on uterine artery blood flow 1 year after insertion. Ultrasound Obstet Gynecol 2006; 27: 316-9. [CrossRef] 